\title{
Protective Effect of Ethanol Extract Tempuyung Leaf (Sonchus arvensis L.) Against Gentamicin Induced Renal Injury Viewed from Blood Ureum Level
}

\author{
Imelda*, Cherry Azaria*, Teresa Lucretia* \\ * Histology Department Faculty of Medicine Maranatha Christian University \\ Jl. Prof. Drg. Suria Sumantri MPH No. 65 Bandung 40164 Indonesia \\ Email:email2imel@gmail.com
}

\begin{abstract}
Acute renal injury is characterized by decrement of glomerular filtration rate (GFR), resulting in nitrogen metabolic end product retention such as blood ureum. Aminoglycoside nephrotoxic injuries are common in elderly, with mortality rate 50-70\%. Tempuyung has been empirically used in relieving renal problems as it contains several active antioxidants. This study aimed to analyze the protective effect of ethanol extract tempuyung leaf (EET) against gentamicin induced renal injury viewed from blood ureum level. The method used was true experimental laboratory, 16 wistar male rats, divided into 4 groups $(n=4)$ : negative control group $(C M C)$, positive control group (Gentamicin $80 \mathrm{mg} / \mathrm{kgBW}$ ), $1^{\text {st }}$ treatment group (EET 100 $\mathrm{mg} / \mathrm{kgBW}+$ Gentamicin), $2^{\text {nd }}$ treatment group (EET $200 \mathrm{mg} / \mathrm{kgBW}+$ Gentamicin) for ten days. On the $11^{\text {th }}$ day, blood serum were taken and the ureum level were analyzed. Data was analyzed by ANOVA and post hoc LSD test. Result showed positive control group had the highest blood ureum level $(29.50 \pm 1.29 \mathrm{mg} / \mathrm{dL})$ compared to negative control group $(14.25 \pm 1.26 \mathrm{mg} / \mathrm{dL}), 1^{\text {st }}$ treatment group $(26.50 \pm 0.58 \mathrm{mg} / \mathrm{dL})$, and $2^{\text {nd }}$ treatment group $(22.25 \pm 1.26 \mathrm{mg} / \mathrm{dL})$ with significance difference $(p<0,001)$. In conclusion, the result suggested the protective effect of EET against gentamicin induced renal injury.
\end{abstract}

Keywords: acute renal injury, gentamicin, glomerular filtration rate, tempuyung, ureum 


\title{
Efek Proteksi Ekstrak Etanol Daun Tempuyung (Sonchus arvensis L.) terhadap Kerusakan Ginjal Akibat Induksi Gentamisin Ditinjau dari Kadar Ureum Darah
}

\author{
Imelda*, Cherry Azaria*, Teresa Lucretia* \\ *Bagian Histologi Fakultas Kedokteran Universitas Kristen Maranatha \\ Jl. Prof. Drg. Suria Sumantri MPH No. 65 Bandung 40164 Indonesia \\ Email: email2imel@gmail.com
}

\begin{abstract}
Abstrak
Gangguan ginjal akut ditandai dengan penurunan laju filtrasi glomerulus (LFG), menyebabkan retensi sisa metabolisme nitrogen, satu diantaranya adalah ureum darah. Insidensi nefrotoksisitas akibat obat golongan aminoglikosida umum terjadi pada kelompok usia lanjut dengan angka mortalitas 50-70\%. Tempuyung telah dipakai sejak dulu sebagai obat tradisional, untuk mengatasi gangguan ginjal karena kandungan sejumlah antioksidan. Tujuan penelitian ini untuk melihat efek proteksi Ekstrak Etanol Daun Tempuyung (EET) terhadap kerusakan ginjal akibat induksi gentamisin dilihat dari kadar ureum darah. Metode berupa eksperimental laboratorik, 16 tikus Wistar jantan dibagi menjadi 4 kelompok $(n=4)$ : kelompok kontrol negatif (CMC), kelompok kontrol positif (Gentamisin $80 \mathrm{mg} / \mathrm{kgBB}$ ), kelompok perlakuan 1 (EET 100 $\mathrm{mg} / \mathrm{kgBB}+$ gentamisin), dan kelompok perlakuan 2 (EET $200 \mathrm{mg} / \mathrm{kgBB}+$ gentamisin) selama sepuluh hari. Pada hari ke-11 darah diambil dan diperiksa kadar ureum.darah Data dianalisis dengan uji statistik ANOVA dan uji beda rata-rata LSD. Hasil menunjukkan kelompok kontrol positif dengan ureum tertinggi $(29.50 \pm 1.29 \mathrm{mg} / \mathrm{dL})$ bila dibandingkan dengan kelompok kontrol negatif $(14.25 \pm 1.26 \mathrm{mg} / \mathrm{dL})$, kelompok perlakuan $1(26.50 \pm 0.58 \mathrm{mg} / \mathrm{dL})$, dan kelompok perlakuan $2(22.25 \pm 1.26 \mathrm{mg} / \mathrm{dL})$, dengan perbedaan yang bermakna $(\mathrm{p}<0,001)$. Kesimpulan hasil menunjukkan efek proteksi EET terhadap kerusakan ginjal akibat induksi gentamisin.
\end{abstract}

Kata kunci: gangguan ginjal akut, gentamisin, laju filtrasi glomerulus, tempuyung, ureum 


\section{Pendahuluan}

Gangguan ginjal akut merupakan suatu sindroma penurunan laju filtrasi glomerulus (LFG), yang menyebabkan retensi sisa metabolisme nitrogen, yaitu kadar ureum serta terganggunya homeostasis cairan, elektrolit, dan asam basa. Nekrosis tubular akut (NTA) merupakan gambaran histopatologis tersering (80\%) dari keadaan gangguan ginjal akut (GnGA) / acute kidney injury (AKI). ${ }^{1-4}$

Etiologi gangguan ginjal akut dapat dibagi menjadi tiga, berdasarkan patofisiologinya, yaitu prerenal (ditandai dengan hipoperfusi ginjal tanpa disertai kerusakan ginjal), intrinsik (meliputi kerusakan parenkim ginjal) dan postrenal (berhubungan dengan obstruksi akut saluran kemih). Pada GnGA intrinsik, NTA dapat terjadi melalui dua mekanisme, yaitu proses iskemia (akibat faktor endogen) dan proses nefrotoksik (akibat faktor eksogen). NTA yang diakibatkan gentamisin merupakan kejadian tersering pada NTA intrinsik proses nefrotoksik. ${ }^{3-7}$

Insidensi terjadinya GnGA berkisar 3-7\% dari total kasus rawat inap. Insidensi nefrotoksisitas akibat obat golongan aminoglikosida mengalami kecenderungan meningkat dari 2-3\% (tahun 1969) menjadi 20\% (2007). Hal ini sedikit banyak berkaitan dengan tingginya beban biaya kesehatan, khususnya di negara berkembang, seperti di Indonesia. Keadaan ini umumnya terjadi pada kelompok usia lanjut dan timbul dengan atau tanpa penyakit penyerta. Secara umum, angka mortalitas akibat NTA masih relatif tinggi, yaitu sekitar 50-70\%.,

Kerusakan NTA akibat gentamisin umumnya berlokasi pada sel epitel tubulus proksimal segmen awal. Gentamisin berikatan kuat dengan asam fosfoinositid pada brush border bagian apikal membran dari tubulus proksimal ginjal. Gentamisin, via reseptor megalin, masuk ke dalam sel tubulus secara endositosis. Di dalam sel, gentamisin melalui jalur utama, yaitu menuju lisosom. Jalur alternatif, via transpor retrograde, gentamisin bergerak dari kompleks golgi menuju retikulum endoplasma, sebelum akhirnya bertranslokasi ke sitosol. ${ }^{3,8-10}$

Penelitian Karasawa dan Servais dkk, mengemukakan bahwa akumulasi gentamisin dapat mengganggu permeabilitas lisosom sehingga terjadi "lysosomal burst", yaitu pecahnya membran lisosom diikuti keluarnya enzim protease, seperti 
cathepsin dan gentamisin ke dalam sitosol. Keadaan ini dapat menginduksi sejumlah jalur kematian sel, meliputi nekrosis, dan apoptosis. ${ }^{11-14}$

Menurut Quiros dkk, isi dari lisosom yang masuk ke sitosol, dapat berupa gentamisin yang mengaktivasi mediator pro-apoptosis, Bax. Gentamisin yang keluar dari "lysosomal burst" bersamaan dengan transport retrograde menyebabkan Endoplasmic Reticulum (ER) stress. Selain itu, cathepsin memicu terjadinya proteolisis secara masif sehingga terjadi nekrosis. Konsentrasi gentamisin juga memegang peranan penting, yaitu pada konsentrasi tinggi, jalur kematian yang teraktivasi berupa apoptosis selain ditandai dengan sejumlah stress organel dan inhibisi sintesis protein. Akan tetapi, pada dosis akumulasi gentamisin yang ekstrim berlebihan, cathepsin akan mempercepat proses proteolisis dan rendahnya ATP menghentikan apoptosis dan mengaktivasi jalur kematian berupa necrosis-like cell death. Pada keadaan ekstrim ini, terjadi peningkatan ROS dan terjadi kerusakan struktur sel, organel serta proses metabolik. ${ }^{12,13}$ Nekrosis tubular akut akibat gentamisin pada umumnya bersifat reversibel. Proses penyembuhannya relatif lambat, yaitu berkisar empat sampai enam minggu sejak penggunaan gentamisin dihentikan. Proses penyembuhan nekrosis tubular akut membutuhkan waktu yang lebih panjang lagi, khususnya pada kelompok usia lanjut. ${ }^{3,10}$

Tanaman tempuyung (Sonchus arvensis L.) merupakan tanaman herbal, yang tumbuh liar di pulau Jawa. Tanaman tempuyung telah digunakan sejak dulu sebagai obat tradisional, umum dipakai untuk mengatasi gangguan yang berhubungan dengan organ ginjal karena bersifat meluruhkan batu ginjal dan diuretik. Tanaman tempuyung diketahui mengandung sejumlah zat aktif yang memiliki sifat antioksidan. ${ }^{15,16}$

Zat aktif yang terkandung dalam tanaman tempuyung, di antaranya seperti flavonoid (cathecin, myricetin, rutin, quercetin, kaempferol, orientin dan hyperuside); asam fenol (cinnamic acid); terpenoid (karotenoid dan saponin); alkaloid serta vitamin B dan C. Aktivitas flavonoid sebagai antioksidan, dengan cara mencegah pembentukan radikal bebas dengan daya ikatnya terhadap logam besi (metal chelating). Selain itu, flavonoid juga dapat memutus reaksi berantai radikal bebas dengan cara membersihkan radikal bebas (free radical scavenging). ${ }^{15,16}$

Menurut penelitian Khan dkk pada tahun 2011 diketahui bahwa daun tempuyung bersifat renoprotektif terhadap kerusakan yang diakibatkan oleh karbon 
tetraklorida. Hasil penelitian Yin dkk pada tahun 2007, kembali menegaskan kandungan asam fenol dan flavonoid dari daun tempuyung yang memiliki potensi sebagai antioksidan alami. $^{15,17,18,19}$

Dalam penelitian ini, daun tempuyung yang digunakan adalah spesies Sonchus arvensis L. Hal ini disebabkan spesies ini merupakan spesies yang umum terdapat di Indonesia dan diketahui mengandung aktivitas antioksidan, meliputi flavonoid dan asam fenol. Ketidakmampuan pengobatan konvensional dalam meminimalisasi kerusakan oksidatif pada nekrosis tubular akut akibat gentamisin merupakan alasan maraknya pengobatan alternatif. Namun demikian, selama ini belum ada penelitian yang secara khusus dilakukan untuk melihat potensi antioksidan dari tanaman tempuyung, khususnya spesies Sonchus arvensis L. terhadap stres oksidatif pada nekrosis tubular akut di Indonesia. ${ }^{13-18}$

\section{Metode}

Desain penelitian ini adalah eksperimental laboratorium sungguhan dengan rancang acak lengkap. Tahap pertama adalah pembuatan ekstrak etanol menggunakan cara maserasi sederhana dari daun tempuyung yang diperoleh dari perkebunan di daerah Lembang. Selanjutnya dilakukan pengujian terhadap hewan coba, menggunakan tikus Wistar jantan. Sejumlah 16 ekor hewan coba dibagi secara acak ke dalam 4 kelompok $(\mathrm{n}=4)$, yaitu kelompok kontrol negatif (CMC 0,5\%), kelompok kontrol positif (gentamisin 80 mg/kgBB), kelompok perlakuan 1 (Ekstrak Etanol Tempuyung/EET 100 mg/kgBB), dan kelompok perlakuan 2 (EET 200 mg/kgBB). Selain kelompok kontrol negatif, semua hewan coba diinduksi dengan gentamisin dosis $80 \mathrm{mg} / \mathrm{kgBB} / \mathrm{hari}$ secara intraperitoneal (IP), selama 10 hari berturut-turut. Selain gentamisin, kelompok perlakuan 1 dan 2 juga diberikan dosis ekstrak etanol daun tempuyung yang berbeda. Pada hari ke-11, darah tikus diambil dan dilakukan pemeriksaan kadar serum ureum darah. Data yang didapat dianalisis dengan menggunakan uji statistik ANOVA yang dilanjutkan dengan uji beda rata-rata LSD, dengan $\mathrm{p}<0,05$. 


\section{Hasil}

Hasil pengukuran kadar Ureum pada hewan coba yang telah mendapatkan perlakuan selama 10 hari menunjukkan hasil sebagai berikut:

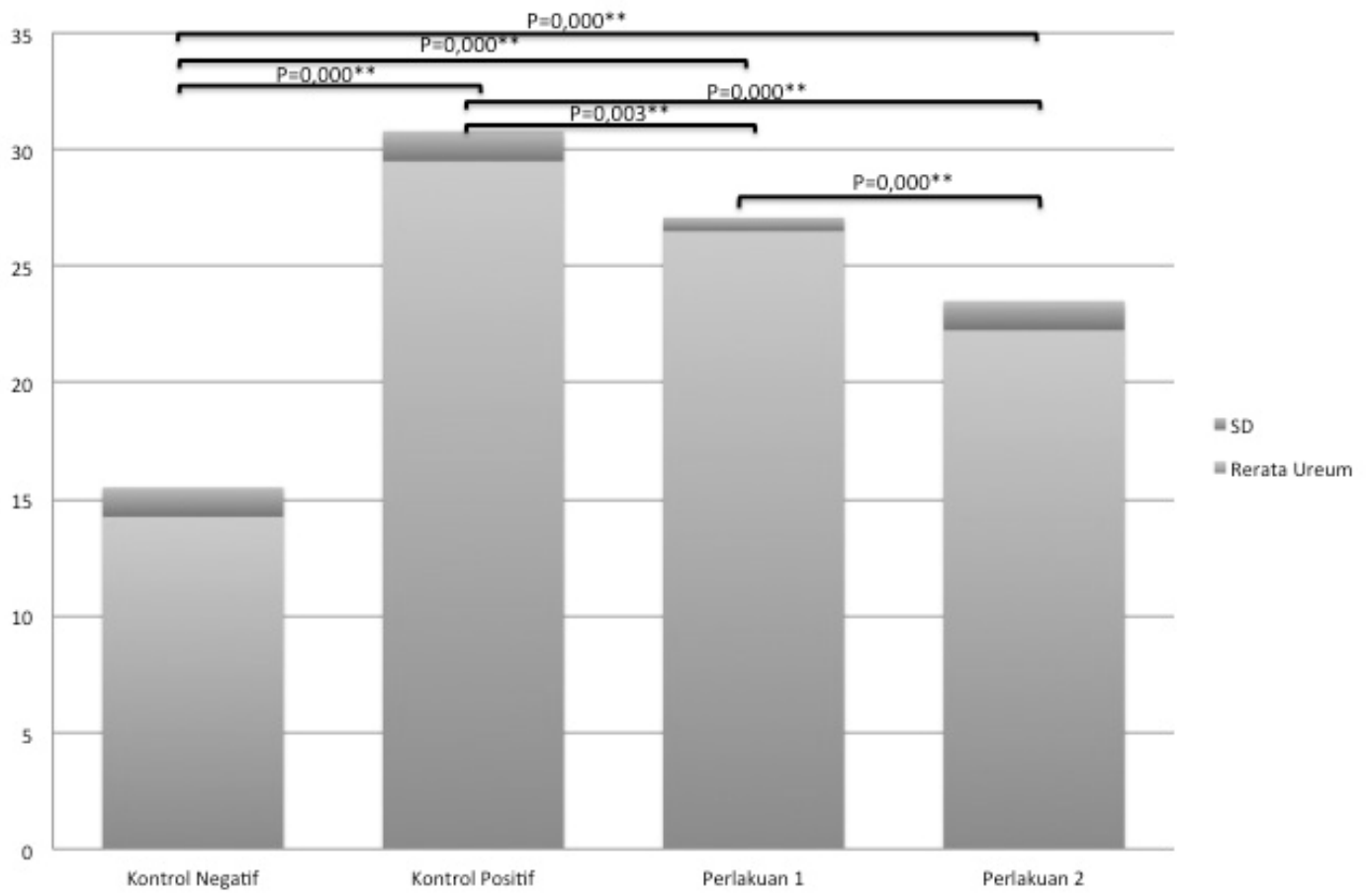

Gambar 1 Kadar Rerata Ureum (mg/dL) \pm SD

Gambar 1 menunjukkan hasil penelitian menggunakan Uji ANOVA menunjukkan $\mathrm{p}=0,00$; yang menunjukkan adanya perbedaan bermakna antara kadar ureum darah pada setidaknya dua kelompok perlakuan. Dilanjutkan post hoc hasil uji beda rata-rata LSD yang pada tiap kelompok menunjukkan adanya perbedaan yang sangat bermakna $(\mathrm{p}<0,005)$.

\section{Diskusi}

Pada pemeriksaan kadar serum ureum darah, setelah pemberian induksi gentamisin selama 10 hari, kelompok kontrol positif menunjukkan rerata kadar serum ureum yang tertinggi $(29,50 \pm 1,29 \mathrm{mg} / \mathrm{dL})$. Hal ini sesuai dengan teori yang menyatakan bahwa pemberian gentamisin dosis tinggi dan dalam jangka waktu lama dapat menyebabkan terjadinya gangguan ginjal akut, mengakibatkan rusaknya epitel 
tubulus ginjal melalui berbagai mekanisme meliputi jalur nekrosis dan apoptosis. Pemberian ekstrak tempuyung, dapat mengurangi proses kerusakan ginjal yang terjadi, terlihat dari rerata kadar ureum kelompok perlakuan $1(26,50 \pm 0,58 \mathrm{mg} / \mathrm{dL})$ dan kelompok perlakuan $2(22,25 \pm 1,26 \mathrm{mg} / \mathrm{dL})$ yang lebih rendah dan berbeda bermakna, bila dibandingkan dengan kelompok kontrol positif. ${ }^{3,8-14}$

Kemampuan renoprotektif tempuyung ini sesuai dengan penelitian yang telah dilakukan sebelumnya. Diduga kandungan zat aktif seperti flavonoid (cathecin, myricetin, rutin, quercetin, kaempferol, orientin dan hyperuside); asam fenol (cinnamic acid); terpenoid (karotenoid dan saponin); alkaloid serta vitamin $\mathrm{B}$ dan $\mathrm{C}$, yang berperan sebagai antioksidan, dapat mencegah pembentukan radikal bebas dengan daya ikatnya terhadap logam besi (metal chelating). Selain itu, flavonoid juga dapat memutuskan reaksi berantai radikal bebas dengan membersihkan radikal bebas (free radical scavenging). ${ }^{13-18}$

Kerusakan epitel tubulus ginjal akibat penggunaan gentamisin bersifat reversibel. Dengan terikatnya radikal bebas, proses kerusakan pada epitel tubulus ginjal akibat pemberian gentamisin yang terjadi terus menerus dapat dicegah. Akibatnya proses penyembuhan dapat berlangsung dengan lebih optimal dan kerusakan permanen pada tubulus ginjal dapat dihindari. ${ }^{3,10}$

\section{Simpulan}

Ekstrak Etanol Daun Tempuyung memberikan efek proteksi terhadap terjadinya kerusakan ginjal akibat induksi gentamisin dilihat dari lebih rendahnya kadar ureum darah.

\section{Daftar Pustaka}

1. Cotran R. Kidney and urinary tract. In: Robbins S, Kumar V, editors. Basic Pathol part II. 4th ed. Philadelphia`: Elsevier Inc; 1995. p. 199-205.

2. Alpers CE. The kidney. In: Robbins Cotran Pathol Basis Dis. 8th ed. Philadelphia: Elsevier Inc; 2010. p. 854-63.

3. Sharfuddin AA, Weisbord SD, Palevsky PM, Molitoris BA. Acute kidney injury. In: Brenner and Rector's The Kidney. 10th ed. Philadelphia: Elsevier Inc; 2016. p. 961-83.

4. Steddon S, Ashman N, Alisatir C, Cunningham J. Acute kidney injury. In: Oxford Handb Nephrol Hypertens. 2nd ed. New York: Oxford University Press; 2014. p. 96-109.

5. Sukandar E. Gagal Ginjal Akut. In: Nefrologi klinik. 4th ed. Bandung: PII Ipede; 2013. p. 518-33.

6. Gondodiputro R. Patofisiologi gangguan ginjal akut. In: Diagnosis dan pengelolaan Gangguan Ginjal Akut. 2nd ed. Jakarta: Puspa Swara; 2011. p. 68-75.

7. Roesli RM. Definisi dan klasifikasi gangguan ginjal akut. In: Diagnosis dan pengelolaan Gangguan Ginjal Akut. 2nd ed. Jakarta: Puspa Swara; 2011. p. 13-21.

8. Tulkens PM, Mingeot-Leclerq M. Aminoglycosides: Nephrotoxicity. Antimicrob Agents Chemother. 
1999;43(5):1003-12.

9. Servais H, Ortiz A, Devuyst O, Denamur S, Tulkens P, Mingeot-Leclercq M. Renal cell apoptosis induced by nephrotoxic drugs: cellular and molecular mechanisms and potential approaches to modulation. Apoptosis. 2008;13:11-32.

10. Sandhu JS, Sehgal A, Gupta O, Singh A. Aminoglycoside Nephrotoxicity Revisited. JIACM. 2007;8(4):331-3.

11. Karasawa T, Steyger PS. Intracellular mechanisms of aminoglycoside-induced cytotoxicity. Integr Biol. 2011;3(9):879-86.

12. Quiros Y, Vicente-vicente L, Morales AI, Lo M, Lo FJ. An Integrative overview on the mechanisms underlying the Renal Tubular Cytotoxicity of Gentamicin. Toxicol Sci. 2011;119(2):245-56.

13. Sancho-martínez SM, López-novoa JM, López-hernández FJ. Pathophysiological role of different tubular epithelial cell death modes in acute kidney injury. Clin Kidney Journ. 2015;8(5):548-59.

14. Van Der Smissen P, Van Der Essen G, Tulkens PM. Gentamicin-induced apoptosis in LLC-PK1 cells: Involvement of lysosomes and mitochondria. Toxicol Appl Pharmacol. 2005;206:321-33.

15. Khan RA. Evaluation of flavonoids and diverse antioxidant activities of Sonchus arvensis. Chem Cent J. 2012;6:1-7.

16. Hussain J, Muhammad Z, Ullah R, Khan FU, Khan IU. Evaluation of the chemical composition of Sonchus eruca and Sonchus asper. J Am Sci. 2010;6(9):231-5.

17. Khan RA, Khan MR, Sahreen S, Jan S. Prevention of CCl 4 induced adrenal oxidative stress in rat by Sonchus asper. J Med Plant Res. 2011;5(15):3347-50.

18. Yin J, Kwon G, Wang M. The antioxidant and cytotoxic activities of Sonchus oleraceus L . extracts. Nutr ResPract. 2007;1(3):189-94.

19. Khan MR, Badar I, Siddiquah A. Prevention of hepatorenal toxicity with Sonchus asper in gentamicin treated rats. BMC Complement Altern Med. 2011;11:3-11. 